\title{
Staining of elastic and muscle fibers to morphometric studies in Chelonia mydas
}

\author{
BRAZ, J. K. F. S. ${ }^{1}$, GOMES, V. L. A. ${ }^{2}$, QUEIROZ, M. S. M. ${ }^{1}$, \\ SILVA, N. B. ${ }^{1}$ and MOURA, C. E. B. ${ }^{2}$ \\ ${ }^{1}$ Departament of Morphology, Universidade Federal do Rio Grande do Norte - UFRN, Av. Senador Salgado Filho, \\ 3000, CEP 59078-970, Natal, RN, Brazil \\ ${ }^{2}$ Department of Animal Science, Universidade Federal Rural do Semi-Árido - UFERSA, Av. Francisco Mota, 572, \\ CEP 59625-900, Mossoró, RN, Brazil \\ *E-mail: jani_karla@yahoo.com.br
}

\begin{abstract}
Introduction: The present study aimed to establish the staining protocol for quantification of elastic fibers and muscle fibers in arterial vessels through the Verhoeff method adapted with eosin in Chelonia mydas. Materials and Methods: Aorta and pulmonary arteries of 11 individuals of the species Chelonia mydas were used. The fragments were fixed in formaldehyde solution buffered $10 \%$ for 24 hours, subjected to routine histological processing and staining technique to be adapted Verhoeff, take the photografies and analyzed by Image Pro Plus Software. Results: The combination of ferric hematoxylin Verhoeff use blushed black elastic arteries blades, already eosin stained muscle fibers and collagen, allowing the tissue quantification through distinction staining by software. Conclusion: The protocol is a low-cost alternative that facilitate the acquisition of morphometric data for research with turtles.
\end{abstract}

Keywords: sea turtle, histomorphology, protocol, eosin, Verhoeff.

\section{Introduction}

The hearts of turtles consists of three chambers: two atria (right and left) and a single ventricle, which in turn is divided into three sub-chambers: the Cavum pulmonale, the Cavum arteriosum and the Carvum venosum, essentially composed of the myocardium, with variations in muscle thickness (VICTOR, NAYAK and RAJASINGH, 1999; WYNEKEN, 2001; MURRAY, 2006).

The great vessels located at the base of the heart of turtles are formed by two aortas, left and right, and two pulmonary arteries, right and left. The right aorta originates the brachiocephalic trunk and the left aorta branches off creating the gastric artery, mesenteric artery and celiac artery (WYNEKEN, 2001). Both the arteries and veins are composed of smooth muscle fibers and elastic fibers, being of great relevance for the distinction of blood vessels by its prevalence in the adventitia and medium tunica (MENDES FILHO and BRITO, 2000). The histomorphological study of the arteries may be related to the ontogeny and behavior of the species (BRAZ, QUEIROZ, OLIVEIRA et al., 2012).

According to Junqueira and Carneiro (2013) smooth muscle fibers of blood vessels are composed of elongated cell associations, with thinner ends and being thicker in the center. They are united and arranged in bundles by a complex network of reticular fibers, ensuring muscle contraction by uniform adhesion of all cells. Furthermore, these authors state that the elastic fibers are formed by microfibrils and elastic components (elastin protein) that constitute the extracellular matrix of connective tissue. This system has the function of uniformly distributing tension while maintaining the resilience of the tissue (USHIKI, 2002). In turn, they form the tissues which have elastomeric properties, such as arteries walls, pulmonary alveolus, skin, tendons and elastic ligaments, and can be identified in light microscopy, by their twisted or linear characteristic and their coloring (ROSS, 1973; USHIKI, 2002).

\section{Short Communication}

According to ROSS (1973) the elastic fibers have affinity for orcein dyes and resorcin-fuchsinin light microscopy. Orcein staining occurs due to the basophilia of the elastic fibers (WEISS, 1953). Resorcin-fuchsin, on the other hand, is a phenolic dye that can react with the collagen fibers and elastic fibers with the addition of additives (NEWTON, 1966). The Verhoeff technique does not use counter stain and it consists of ferric hematoxylin Weighter, iodine, and ferric chloride being the most widely used elastic fibers for viewing under a light microscope. The mordants, iodine, and ferric chloride convert hematoxylin in hematein (JONES, BANCROFT and GAMBLE, 2008).

Because the elastic fibers have high affinity for iron hematoxylin, they acquire stable staining/coloringin black for longer, while other tissues/fabric remain discolored. In this case, it is possible to usecontrast coloring like Van Gieson picrofucsina (JONES, BANCROFT and GAMBLE, 2008). However, picrofuscina is a costly dye without prolonged effect, requiring the use of the polarized light microscopy technique, and its yellow color hinders quantification of muscle fibers and elastic fibers in large vessels byway of morphometry software.

The quantification of elastic fibers and smooth muscle fibers by staining and counterstaining in light microscopy can provide information to help histomorphological characterization and identification of veterinary arterial disorders that lead to injury or malformation of the elastic tissues such as inflammatory 
and fibropapillomas, which are the most frequent in turtles (FLINT, PATTERSON-KANE, LIMPUS et al., 2009). In the case of Fibropapilloma, the proposed protocol can help to more easily quantify the elastic fibers, and therefore to establish tumor aggressiveness patterns appropriately (ORÓS, LACKOVICH, JACOBSON et al., 1999). In addition to assisting in postmortem diagnosis, they provide comparative data for endangered species for biologists and veterinarians, such as the Chelonia mydas species (green turtle).

Therefore, the aim of this study was to establish an affordable protocol for the quantification and analysis of elastic fibers and muscle fibers in arterial vessels of green turtles (Chelonia mydas).

The 11 marine turtles of Chelonia mydas species used were found dead on the coastline of Rio Grande do Norte - Brazil, or died during rehabilitation process at the Natal Aquarium. They were collected upon authorization of TAMAR/ICMBio (License number 21647-1 IBAMA/RN) and approved by the Ethics Committee CEUA/UFRN (Protocol number 047/2009)

Fragments of aorta arteries (left and right) and pulmonary arteries (right and left) were fixed in advance by freezing, and then fixed in $10 \%$ formaldehyde buffered with $0.1 \mathrm{M}$ sodium phosphate $\mathrm{pH} 7.4$ for 24 hours. Next, samples were submitted to routine histological procedures (dehydration, diaphanization and paraffin embedding) and $3 \mu \mathrm{m}$ microtomy as proposed by MAIA (1979). Four slides per specimen were obtained, two of aorta arteries and two 02 from pulmonary arteries, subsequently stained according to the modified Verhoeff technique. They were stained in black by Verhoeff iron hematoxylin in the presence of elastic fibers, and counterstained with eosin muscle fibers, which acquired a pink coloration.

The permanent slides were observed under in Olympus BX4l light microscope (Olympus America Inc., New York, USA) and micro-photographed for analysis and comparison in a microscope with Nikon DXM1200 digital camera (Nikon, Tokyo, Japan), both coupled to a microcomputer. Images captured with the help of Nikon Act-1 software were microphotographed in 4 fields per animal and analyzed by Software Image Pro Plus ${ }^{\circledR}$ (Media Cybernetics, Silver Spring, USA).

Fixation with pre-freezing did not change tissue morphology of the animals, maintaining tissue integrity, likewise for muscle fibers and elastic fibers; this being of utmost importance for analysis and quantification.

Through this protocol, the visualization of aorta and pulmonary arteries walls of $C$. mydas was made possible with elastic fibers stained black by Verhoeff iron hematoxylin attraction, while muscle fibers remained unstained, as expected (Figure 1). Counterstaining was necessary as the Verhoeff method does not stain muscle fibers, which prevents the detection of muscle fibers by the quantification software (ROSS, 1973). Thus, it is possible to obtain morphometric data from these tissues.

The frozen tissue of this species showed satisfactory contrast to eosin, since this dye has an acidic property and a pink color, which facilitates for viewing in light microscopy and hence the quantification of muscle fibers, eliminating the use of polarized light microscopy (RODRIGUES, FAGUNDES NETO, LUCON et al., 2001; JONES, BANCROFT and GAMBLE, 2008; AVOLIO, JONES and TAFAZZOLI-SHADPOUR, 1998). Results obtained by the Verhoeff iron hematoxylin method in light microscopy were positive for Chelonia mydas by having strong affinity for the elastic fibers.

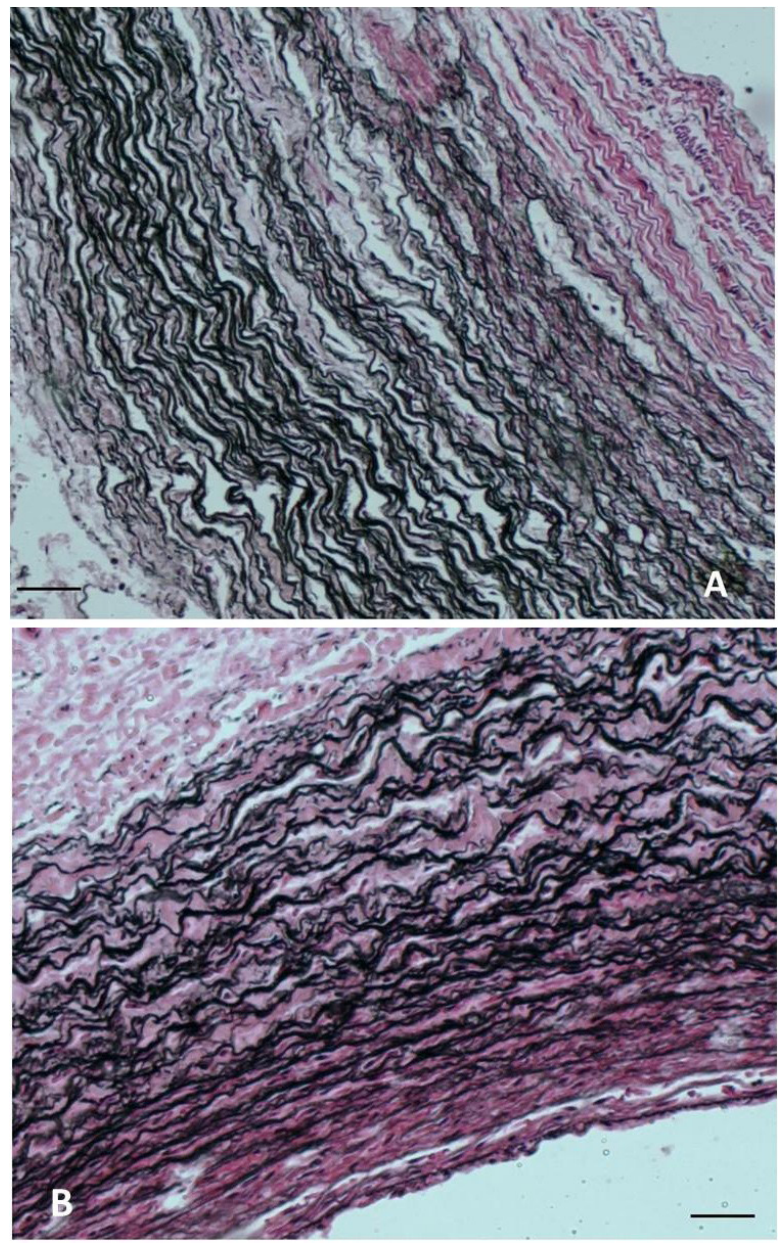

Figure 1. Verhoeff staining method adapted with counterstaining using eosin on Chelonia mydas. The elastic fibers stained black by Verhoeff and muscle fibers stained in red by eosin. (A) Artery aorta; (B) Pulmonary artery. Bar $=100 \mu \mathrm{m}$.

\section{Conclusion}

Counterstaining with eosin along with Verhoeff iron hematoxylin helped in the analysis and quantification of the elastic fibers and muscle fibers in green turtles by image analyzing software, providing an inexpensive tissue distinction to quantify the morphometric analysis in these animals.

Furthermore, this protocol can be used to quantify these elements vessels and other tissues.

Acknowledgements: The Natal Aquarium for supplying animals and the partnership with TAMAR-RN.

\section{References}

AVOLIO, A., JONES, D. and TAFAZZOLI-SHADPOUR, M. Quantification of alterations in structure and function of elastin in the arterial media. Journal of the American Heart Association, 1998, vol. 32, n. 1, p. 170-175. PMid:9674656.

BRAZ, JKFS., QUEIROZ, MSM., OLIVEIRA, MF. and MOURA, CEB. Morfometria do coração e dos vasos da base e sua implicação no mergulho em Chelonia mydas. Pesquisa Veterinaria Brasileira, 2012, vol. 33, p. 32-38. http://dx.doi.org/10.1590/S0100736X2013001300006. 
FLINT, M., PATTERSON-KANE, JC., LIMPUS, CJ., WORK, TM., BLAIR, D. and MILLS, PC. Postmortem diagnostic investigation of disease in free-ranging marine turtle populations: a review of common pathologic findings and protocols. Journal of Veterinary Diagnostic Investigation, 2009, vol. 21, n. 6, p. 733-759. PMid:19901275.

JONES, LM., BANCROFT, JD. and GAMBLE, M. Theory and practice of histological techniques. 6th ed. London: Churchill Livingstone, 2008. 744 p.

JUNQUEIRA, LC. and CARNEIRO, J. Histologia básica. 12th ed. Rio de Janeiro: Guanabara Koogan, 2013. 556 p.

MAIA, V. Técnica histologica. 2nd ed. São Paulo: Atheneu, 1979. p. 70-136.

MENDES FILHO, A. and BRITO, GAC. Histologia prática. 2nd ed. Fortaleza: UFC. 2000. 107 p.

MURRAY, MJ. Cardiopulmonary anatomy and physiology: reptile medicine and surgery. Philadelphia: Elsevier, 2006. p. 124-134.

NEWTON, AV. Collagen, elastic tissue and resorcin fuchsin. Nature, 1966, vol. 209, n. 5028, p. 1146-1147. http://dx.doi. org/10.1038/2091146a0. PMid:5925205.

ORÓS, J., LACKOVICH, JK., JACOBSON, ER., BROWN, DR. TORRENT, A., TUCKER, S. and KLEIN, PA. Fibropapilomas cutáneos y fibropapilomas viscerales en una Tortuga verde (Chelonia mydas). Revista Española de Herpetología, 1999, vol. 13, p. 17-26.
RODRIGUES, CJ., FAGUNDES NETO, HO., LUCON, M., LUPINACCI, R., PETTI, D., RAMOS, LO. and RODRIGUES JUNIOR, AJ. Alterações no sistema de fibras elásticas da fáscia endopélvica de paciente Jovem com prolapso uterino. Revista Brasileira de Ginecologia e Obstetricia, 2001, vol. 23, n. 1, p. 53-55. http:// dx.doi.org/10.1590/S0100-72032001000100008.

ROSS, R. The elastic fiber: a review. The Journal of Histochemistry and Cytochemistry, 1973, vol. 21, n. 3, p. 199-208. http://dx.doi. org/10.1177/21.3.199. PMid:4121415.

USHIKI, T. Collagen fibers, reticular fibers and elastic fibers: comprehensive understanding from a morphological viewpoint. Archives of Histology and Cytology, 2002, vol. 65, n. 2, p. 109-126. http://dx.doi.org/10.1679/aohc.65.109. PMid:12164335.

VICTOR, S., NAYAK, VM. and RAJASINGH, R. Revolution of the ventricle. Texas Heart Institute Journal, 1999, vol. 26, p. 168-176. PMid:10524737.

WEISS, J. The nature of the reaction between orcein and elastin. The Journal of Histochemistry and Cytochemistry, 1953, vol. 2, n. 1, p. 21-28. http://dx.doi.org/10.1177/2.1.21. PMid:13118135.

WYNEKEN, J. The anatomy of sea turtle. Washington: NOAA, 2001. 172 p.

Received June 19, 2015

Accepted July 6, 2016 